Jan Milbrink PhD MD, * Gunnar Birgegård PhD MD, * Antero Danersund MD, * Claes Helmers PhD MD, ${ }^{\dagger}$ Lars Nordström MSc PHARM, ${ }^{\dagger}$ Bo Sandhagen PhD*

\section{Preoperative autologous donation of 6 units of blood during rh-EPO treatment}

\begin{abstract}
Purpose: To determine if donation of six units of blood in three weeks is possible with self-administered subcutaneous recombinant human erythropoietin (ihEPO) injections and oral iron treatment.

Methods: A prospective trial where a total of 32 otherwise healthy patients were phlebotomised before revision hip arthroplasty during ihEPO and oral iron treatment (ferrofumarate). Adverse events were noted and compliance was controlled. Routine laboratory tests were performed at each visit including reticulocytes and 2,3-DPG. The relative oxygen releasing capacity (RORC) and the oxygen releasing capacity (ORC) were calculated. Blood donation was postponed until the next visit if haemoglobin concentrations was $<115 \mathrm{~g}^{-1}$ (men) or $<105 \mathrm{~g}^{-1}$ (women).

Results: All but two patients were able to donate six units of blood with an acceptable haemoglobin concentration on the day of operation. One serious adverse event occurred when the $\mathrm{Hb}$ was $119 \mathrm{~g} . \mathrm{H}^{-1}$, compared with $149 \mathrm{~g}^{.1} \mathrm{H}^{-1}$ before treatment. During the first two weeks before phlebotomy there was no increase in $\mathrm{Hb}$, the mean nadir was reached atter six phlebotomies ( $31 \mathrm{~g}^{-1^{-1}}$ below pre-study level), while at operation it was $19 \mathrm{~g} \cdot \mathrm{l}^{-1}$ below pre-study level. There was an increase in 2,3-DPG and oxygen releasing capacity after the initiation of riEPO therapy, before the first phlebotomy.

Conclusion: It is possible to donate six units of blood in a three week period before surgery during self-administered subcutaneous inEPO treatment and oral iron therapy at a ihEPO dose of $60 \mathrm{U} \cdot \mathrm{kg}^{-} \mathrm{BW}$ three times a week. It is suggested that inEPO per se initiates a right-shift of the oxygen dissociation curve via an increased 2,3-DPG level, which could explain that some patients report subjective benefit of $m E P O$ in spite of no change in $\mathrm{Hb}$ concentration.
\end{abstract}

Objectif : Déterminer s'il est possible de prélever six unités de sang en trois semaines avec l'appoint de l'érythropoḯtine recombinante humaine ( $(\mathrm{HEPO}$ ) en injections sous-cutankes auto-administrées et de la sidérothérapie orale. Méthodes : Cette étude prospective regroupait 32 patients bien portants phébotomisés avart une revision d'arthroplastie de la hanche et l'administration orale de fer (ferrofumarate). Les réactions secondaires ont été notées et la compliance controlée. Les épreuves de laboratoire usuelles effectuées à chaque visite induaient le réticulocytose et les 2,3-DPG. La capacité relative de relargage de l'oxygène (RORC) et la capacité de relargage de l'oxygène (ORC) ont été calculées. On reportait le don sanguin jusqu'à la visite suivante si la concentration d'hémoglobine était <115 $\mathrm{g}^{-1} \mathrm{~L}^{-1}$ (hommes) ou $<105 \mathrm{~g} \cdot \mathrm{L}^{-1}$ (femmes).

Résultats : Tous les patients à l'exception de deux ont pu donner six unités de sang tout en maintenant une concentration en hémoglobine acceptable le jour de l'intervention. Une complication grave est survenue quand l'Hb était $119 \mathrm{~g}^{\circ} \mathrm{L}^{-1}$, comparativement à $149 \mathrm{~g} \cdot \mathrm{L}^{-1}$ avant traitement. L'hémoglobine n'a pas augmenté pendant les deux premières semaines qui précédaient la phlébotomie et la valeur moyenne la plus basse était atteinte après six phlébotomies ( 3 I g. $\mathrm{L}^{-1}$ sous le niveau antérieur à l'étude), alors qu'au moment de l'intervention l'Hb était $19 \mathrm{~g} \cdot \mathrm{L}^{-1}$ sous le niveau antérieur à l'étude. Les 2,3-DPG et la capacité de largage de l'oxygène augmentaient après le début du traitement au $\mathrm{h} E \mathrm{EPO}$ avant la première phlebotomie.

Conclusion : II est possible de faire un don de six unités de sang en trois semaines avant la chinurgie pendant l'autoadminsitration sous-cutanée du traitement au rhEPO à la dose de $60 \mathrm{U} \cdot \mathrm{kg}^{-1}$ trois fois par semaine et la sidérothérapie orale. Il est suggéré que per se le ihEPO induit un déplacement vers la droite de la courbe de dissociation de l'hémoglobine par augmentation du niveau des 2,3-DPG, ce qui pourrait expliquer le bienfait subjectif du rhEPO décrit par certains patients malgré l'absence de changements de la concentration de l'hémoglobine.

From the Departments of Orthopedics (Dr. Milbrink); Internal Medicine (Dr. Birgegárd); Transfusion Medicine (Dr. Danersund); Medical Technology (Sandhagen) University Hospital, Uppsala* and Boehringer-Mannheim Scandinavia, ${ }^{\dagger}$ Sweden. Address correspondence to: Jan Milbrink PhD MD, Department of Orthopedic Surgery, University Hospital, S-751 85 Uppsala, Sweden.

Phone: +4618663000 ; Fax: +4618509427

Accepted for publication October 1, 1997. 
$\mathrm{T}$

RANSFUSION of predonated autologous blood is the safest way to restitute operative blood loss, ${ }^{1}$ and for healthy patients, with a haemoglobin $(\mathrm{Hb})$ concentration $>120 \mathrm{~g} \cdot \mathrm{l}^{-1}$ in men and $>110 \mathrm{~g} \cdot \mathrm{l}^{-1}$ in women, four units can be donated within 12 days, two weeks before operation. ${ }^{2}$ However, only a limited part of an unselected patient group could donate as many as six units during four weeks. $^{3}$

To increase the efficacy of autologous blood transfusions, administration of recombinant human erythropoietin (rhEPO) is effective in both orthopaedic ${ }^{4-7}$ and open heart surgery. ${ }^{8-10}$ patients. Since rhEPO is expensive, determination of the optimal dose, and of the interval and route of administration is important. ${ }^{11}$

The aim of our study was to investigate if donation of six units of blood in three weeks was possible with self-administered rhEPO treatment $s c$ during iron treatment po. We also studied erythrocyte 2,3-diphospho-glycerate (2,3-DPG) and calculated the oxygen releasing capacity.

\section{Methods}

After informed consent and approved by the local ethics committee and Medical Products Agency, 36 parients $575 \mathrm{yr}$, scheduled for revision hip arthroplasty were studied. Initially, patients were randomised to receive rhEPO (Recormon ${ }^{\otimes}$, Boehringer Mannheim), $60 \mathrm{U} \cdot \mathrm{kg}^{-1} \mathrm{sc}$ either three or six times a week during six weeks before operation. After studying 17 patients, and finding no difference between the two doses, the study was limited to determine if, with a low dose regimen, it would be possible to donate six units over six weeks.

Study drug treatment was given for two weeks before the first phlebotomy and continued for six weeks until surgery. Phlebotomy was performed twice weekly for three weeks. Iron supplement, $120 \mathrm{mg} \cdot$ day $^{-1}$ po was given for two weeks increasing to $240 \mathrm{mg}$ with blood donation.

If the haemoglobin was $<115 \mathrm{~g} \cdot \mathrm{l}^{-1}$ in men and $<105 \mathrm{~g} \cdot \mathrm{l}^{-1}$ in women, donation was postponed. At each visit, patients were asked about problems with the injections and compliance was controlled. Surgical blood loss was recorded.

Blood samples for 2,3-DPG were drawn, acid-precipitated and the supernatants frozen. All 2,3-DPG analysis was performed at one time (Boehringer Mannheim). The relative oxygen releasing capacity (RORC) was calculated according to SiggaardAndersen $e$ t al. ${ }^{12}$ assuming $\mathrm{PaO}_{2}$ of $12 \mathrm{kPa}$ and venous $\mathrm{PO}_{2}$ of $5 \mathrm{kPa}$ and normal values for $\mathrm{pH}$ and $\mathrm{PCO}_{2}$. The oxygen releasing capacity (ORC) was calculated as $\mathrm{RORC} \times \mathrm{Hb} \times 0.062$. For comparison, ORC was calculated both with an assumed normal value and the measured value of 2,3-DPG.

\section{Results}

Two patients were excluded because of poor veins, one because of suspected malignancy, and one because of hepatitis $\mathrm{C}$ antibodies. After 17 patients had completed the programme, and since no clinically relevant differences could be detected regarding haemoglobin change, randomisation was abandoned and only the lower dose regimen was continued. Therefore, eight patients received $60 \mathrm{U} \cdot \mathrm{kg}^{-1} \mathrm{BW}$ rhEPO six times a week and 24 received $60 \mathrm{U} \cdot \mathrm{kg}^{-1} \mathrm{BW}$ three times a week. The 19 men and 13 women had a mean age of $64 \mathrm{yr}$ (range $-45-75$ ).

One patient had a non fatal myocardial infarction after the last phlebotomy, when the haemoglobin was 119 g. $\mathrm{L}^{-1}$, compared with $149 \mathrm{~g} \cdot \mathrm{L}^{-1}$ before treatment. $\mathrm{He}$ was later operated upon after cardiological evaluation.

There was no increase in haemoglobin concentration during the two weeks of rhEPO treatment before phlebotomy. After six phlebotomies a nadir was reached at $112 \mathrm{~g} \cdot \mathrm{L}^{-1}, 31 \mathrm{~g} \cdot \mathrm{L}^{-1}$ below the pre-study level. At operation, mean $\mathrm{Hb}$ was $124 \mathrm{~g} \cdot \mathrm{L}^{-1}$, or $19 \mathrm{~g} \cdot \mathrm{L}^{-1}$ (see Figure 1). The mean reticulocyte count increased to $6 \%$ after three phlebotomies and remained at this level until operation.

All but two patients donated six units of blood. They belonged to the lower dose group, due to low haemoglobin concentration. The total mean blood loss was 2.7 liters (range $0.8-7.7$ l), 4.6 units (range $0-14$ ) were transfused, and $77 \%$ of the predonated blood was utilised. Five patients required additional homologous blood transfusions, due to excessive bleeding ( $>3500 \mathrm{ml})$.

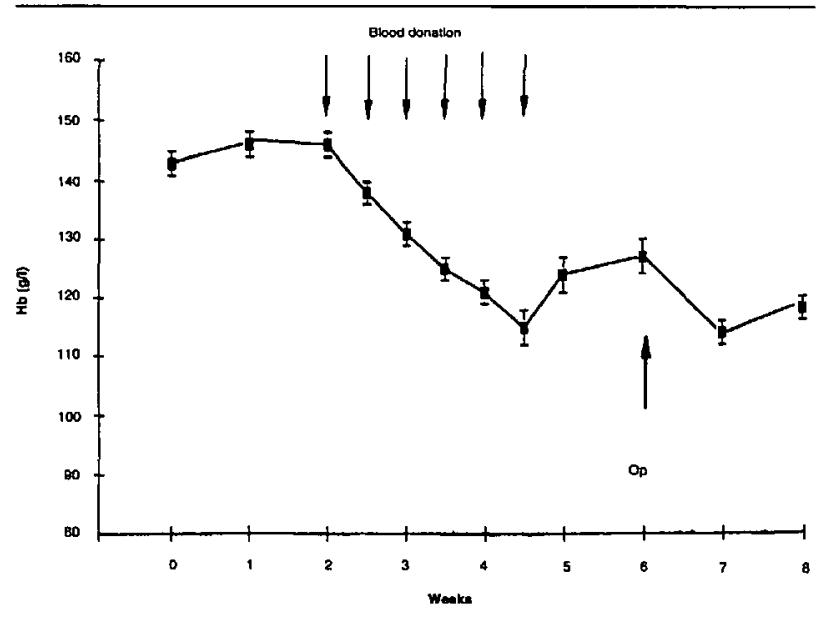

FIGURE 1 Hacmoglobin values during the study. 
Calculated using an assumed normal 2,3-DPG, ORC decreased from the first phlebotomy throughout the study (see Figure 2b). However, the mean 2,3-DPG level increased, from the start of the study, when the rhEPO treatment was initiated (see Figure 2a). The resulting right-shift of the oxygen dissociation curve increased the oxygen releasing capacity. After the start of phlebotomies, ORC decreased along with the $\mathrm{Hb}$ concentration, but returned to normal before operation (see Figure $2 b$ ). The mean 2,3-DPG level continued to increase after the start of phlebotomies, levelled out before operation and again increased postoperatively (see Figure $2 \mathrm{a}$ ).

\section{Discussion}

The rhEPO treatment was started two weeks before phlebotomy to initiate early increased erythropoietic activity. The increase in reticulocytes indicated that this was successful. There was no rise in $\mathrm{Hb}$ concen-

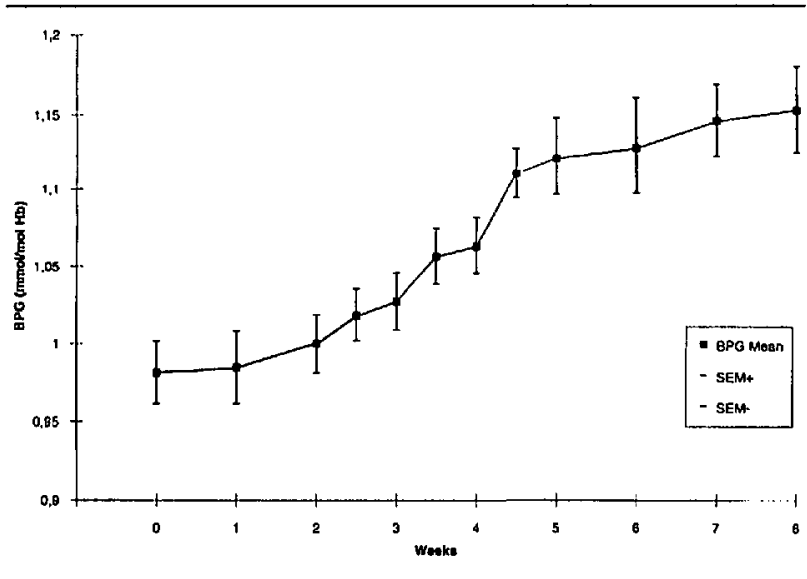

FIGURE 2A 2,3-DPG values during the study. Mean \pm SEM.

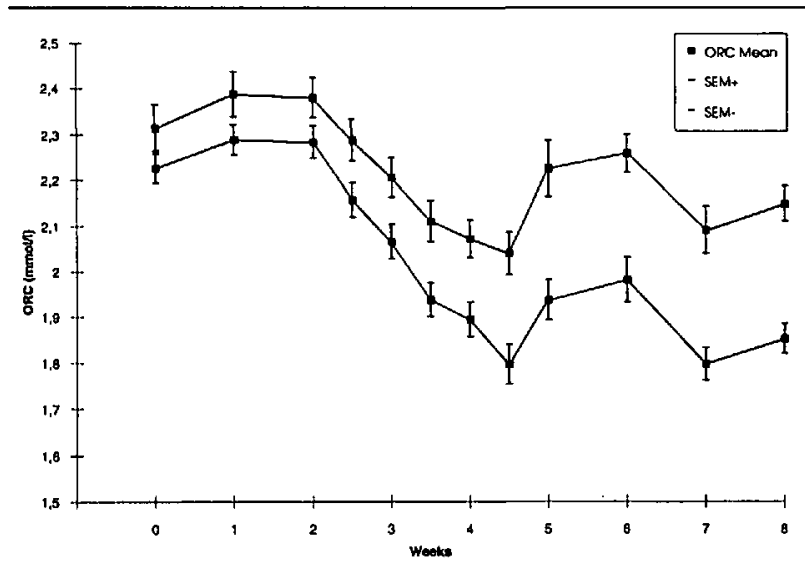

FIGURE 2B Oxygen releasing capacity during the study. Lower curve with an assumed normal 2,3-DPG concentration. Upper curve with the 2,3-DPG increase taken into account. tration during these two weeks. With this rhEPO regimen, we collected six units of blood in 30 patients and five units in two. The total dose, $1080 \mathrm{U} \cdot \mathrm{kg}^{-1}$, lower than in most studies is important, because of the high cost of rhEPO which is a deterrent in predonation programs. ${ }^{13}$ The difference in $\mathrm{Hb}$ level between phlebotomy and surgery of $19 \mathrm{~g} \cdot \mathrm{l}^{-1}$ was acceptable. The administration of rhEPO is more cost effective by the $s c$ than be the $i v$ route ${ }^{14}$ Our study shows that patients after very limited instruction can learn to handle the subcutaneous injections.

There were no side effects of rhEPO treatment although the myocardial infarction in an otherwise healthy 59 -yr-old man may have been caused by the diminished $\mathrm{Hb}$. It may be wise to exclude patients with any cardiovascular disease from such therapy.

The 2,3-DPG curve increased after initiation of rhEPO treatment before phlebotomy and continued to increase during phlebotomy to level out one week later, probably due to the concomitant increase of the $\mathrm{Hb}$. After it increased again, probably due to the blood loss.

During phlebotomy ORC decreased in spite of the increased 2,3-DPG level, but normalised before the operation. If rhEPO treatment initiates a right-shift of the oxygen dissociation curve via increased 2,3-DPG, this may explain why some patients report subjective benefit from rhEPO treatment without any change in $\mathrm{Hb}$.

We conclude that it is possible to donate six units of blood preoperatively during rhEPO and iron therapy: $60 \mathrm{U} \cdot \mathrm{kg}^{-1} \mathrm{rhEPO} s c$ three times per week is sufficient and most patients require little instruction.

\section{Acknowledgments}

This study was supported by Boehringer Mannheim Scandinavia.

The authors thank Gunilla Persson for patient administration work and the Transfusion Medicine Dept, University Hospital, Uppsala, Sweden, for administration of phlebotomies and collected blood units.

\section{References}

1 Goodnough LT, Shafron D, Marcus RE. The impact of preoperative autologous blood donation in orthopaedic surgical practice. Vox Sang 1990; 59: 65-9.

2 Birgegård $G$, Danersund A, Högman C, Milbrink J, Wide $L$. Physiological response to phlebotomies for autologous transfusion at elective hip-joint surgery. Eur J Haematol 1991; 46: 136-9.

3 Goodnough LT, Price TH, Friedman KD, et al. A phase III trial of recombinant human erythropoictin therapy in nonanemic orthopedic patients subjected to aggressive 
removal of blood for autologous use: dose, response, toxicity, and efficacy. Transfusion 1994; 34: 66-71.

4 Giuse $H G$, Wens $K$, Behr $W$, et al. Preoperative autologous blood donation with rhEPO therapy in patients scheduled for cardiac surgery: preliminary results of a dose-response finding multicenter trial. In: Bauer CKK, Scigalla P, Wieczorek L (Eds.). Erythropoietin: Molecular Physiology and Clinical Applications. New York: Dekker Inc, 1993: 411-24.

5 Kyo S, Omoto R, Hirasbima K, Egucbi S, Fajita $T$. Effect of human recombinant erythropoietin on reduction of homologous blood transfusion in open-heart surgery. Circulation 1992; 86: II-413-8.

6 Mercuriali $F$, Zanella $A$, Barosi $G$, et al. Use of erythropoietin to increase the volume of autologous blood donated by orthopedic patients. Transfusion 1993; 33: 55-60.

7 Murphy $P$, Heal JM, Blumberg $N$. Infection or suspected infection after hip replacement surgery with autologous or homologous blood transfusions. Transfusion 1991; 31: 212-7.

8 Onvings DV, Kruskall MS, Thurer RL, Donovan LM. Autologous blood donations prior to elective cardiac surgery. Safety and effect on subsequent blood use. JAMA 1989; 262: 1963-8.

9 Osswald PM, Osmers $A$, Lorentz $A$, et al. Dose-response relationship of rhEPO in preoperative autologous blood donation in patients scheduled for elective orthopedic surgery. In: Bauer CKK, Scigalla P, Wieczorek L (Eds.). Erythropoietin: Molecular Physiology and Clinical Applications. New York: Dekker Inc, 1993: 425-41.

10 Pineda AA, Brzica SM Jr, Taswell HF. Hemolytic transfusion reaction. Recent experience in a large blood bank. Mayo Clin Proc 1978; 53: 378-90.

11 Popovsky $M A, A b e l M D$, Moors $S B$. Transfusion-related acute lung injury associated with passive transfer of antileucocyte antibodies. Am Rev Respir Dis 1983; 128: 185-9.

12 Siggaard-Andersen $O$, Wimberly $P D$, Fogh-Andersen $N$, Gathgen $I H$. Measured and derived quantities with modern $\mathrm{pH}$ and blood gas equipment: calculation algorithms with 54 equations. Scand J Clin Lab Invest 1988; 48(Suppl 189): 7-15.

13 Walker $R H$. Special report: transfusion risks. Am J Clin Pathol 1987; 88: 374-8.

14 Bommer J, Barth H-P, Zeier $M$, et al. Efficacy comparison of intravenous and subcutanous recombinant human erythropoietin administration in hemodialysis patients. In: Gurland HJ, Moran J, Samtleben W, Scigalla P, Wieczorek L (Eds.). Erythropoietin in Renal and Non-Renal Anemias. Contrib Nephrol. Basel: Karger 1991; 88: 136-43. 